\title{
Tritium Production Potential of Beam Research and Magnetic Fusion Program Technologies
}

A write paper compiled by J.D. Lee. with input from R.J. Briggs, F.H. Coensgen,

J.H. Hammer, R.R. Hedtke, J.D. Lee, B.G Logan, and R.W. Moir

March 1989

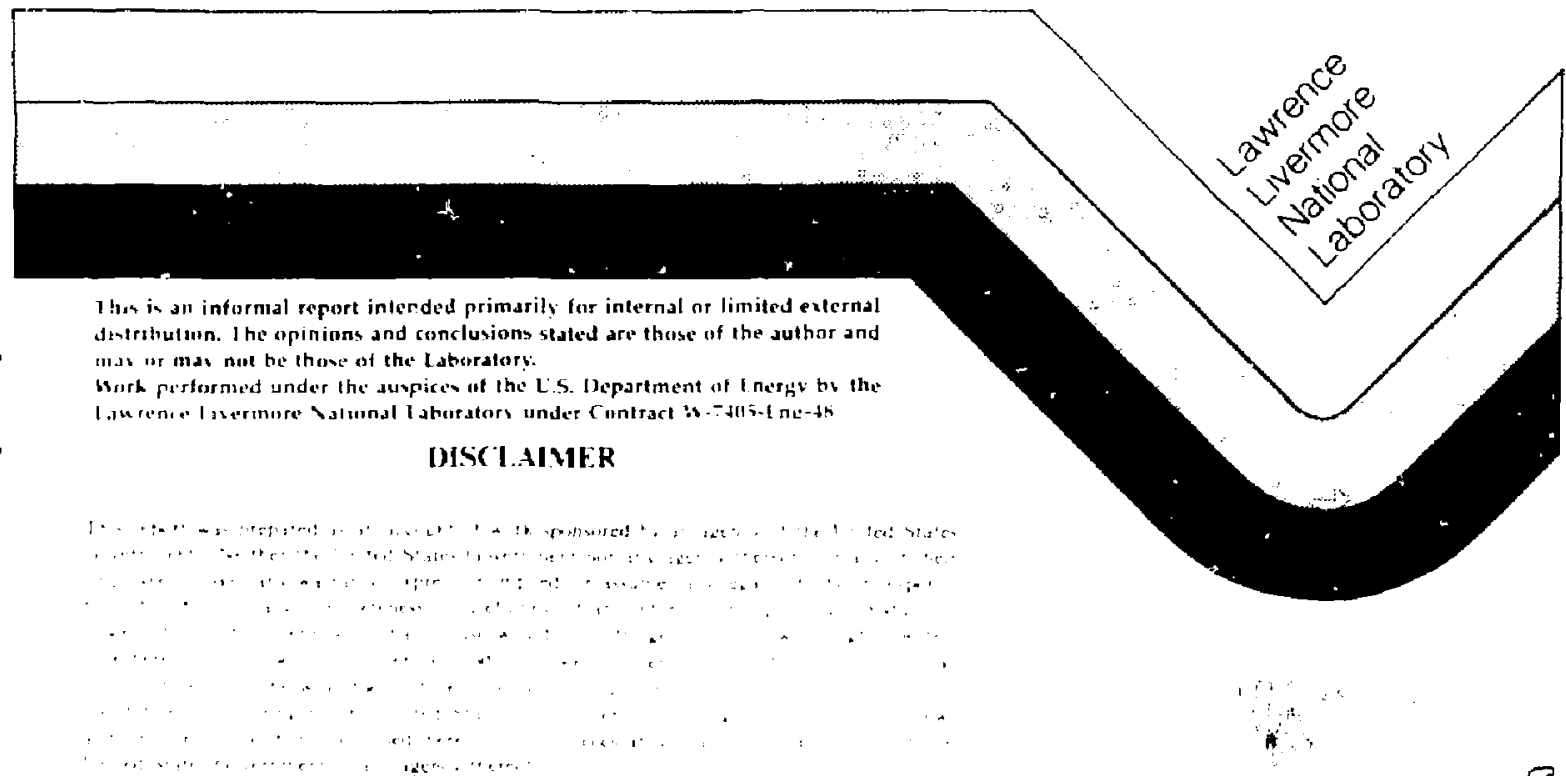




\section{DISCLAIMER}

This dockmenl was prepared as an account of work sponsored by an agency of the United Stales Covernmetat. Neitner the United States Government nor the Univenilly of Californis nor any of their employees, makes any warsenty, express or implied, ar asoumes any lezal liability or responsibltity for the accusacy, completeness, or usefulress of any information, apparalus, product, or peocess dieclosed. or represents that th use would not infringe privalely owned rights. Reference herein to any specific commercial produrts, procese, or service by tesde name, trademark, manufacturer, or otherw ise, doet no: aecenarlity conatitute or imply its endoreement, recommendation, or favoring ty the Uniled States Government or the University of Californis. The views and opinions of authone expreased herein do not necerarily state or reflect those of the United Slates Government or the University of Catifornic and ghall not be ubed fot advertiving or product eadarsement purposes.

\author{
Punted in the Uinited Siates ol Ameriss \\ Araslathe trom

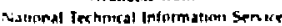 \\ LS Depunment of Commerte \\ 5215s Port Royal Houd \\ Spnngfield va 221 bt
}

Price

Code

Ad]

\section{Papercopy Prices}

A02

A03

AO4

A05

A06

AO7

A08

A09
Microficne

$001-050$

$051-100$

$101-200$

201 -300

501 - 400

401- 500

$50 \mathrm{t}-500$

bol 
Hegular rejplenishment of tritium in the nuclear weaposts suckpile is esmential to maintain our nuclear deterrent. Suclear reaclen facilition presently used for the production of eritimu are aging. and their operation is bring curtailed awating the repairs and upgrades teedert 16 meet mudern standards of safety and environment. To provide improved capability in the

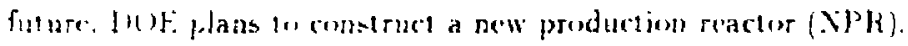

Alternatives 10 nuclear reartur methods for the production of tritium. mainly clectricallydriven acceleratur or fusion systems. have been propused many lime in the past. (ijen the critical national security implications of maintaining adequate tritium production facilities. it is clearly worthwhile for political clecision-makers to have a clear and acrurate picture of the technical options that could be made available at various points in the future.

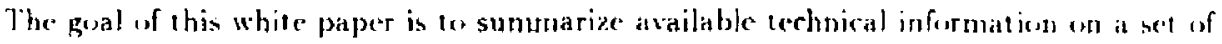
non-nuckear-reactor cptions for ititurn production with a minimum of advesacy for any one

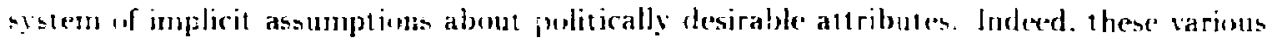

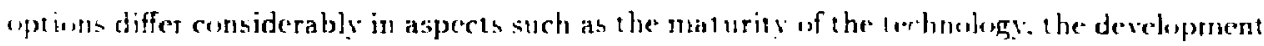
costs and timescales recpuired, and the capital and eperding costh of a typical "eptimized" facilits. For example. a concept that relies an relatively "unproven" physics and ior lechnol. ngy max. herause of simplicity in scaling and or its smatl mudulat nature. have a relatively.

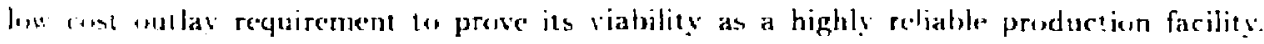
Anober factor co consider is the utilizy of the achnolegy developmert for other purposes: c.g. fuxion sistems for tritium production can be a "stepping stenc" we a commercial puwer

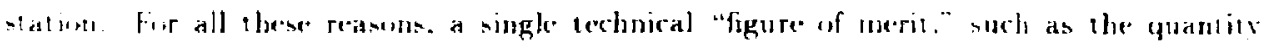




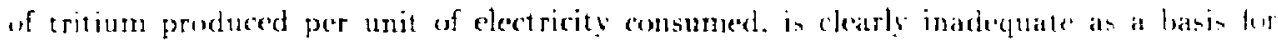
decision makers 1 , understand the tradeotis involved.

It is alse important 10 distinguish the uptions proposed at altematues to the Sple from

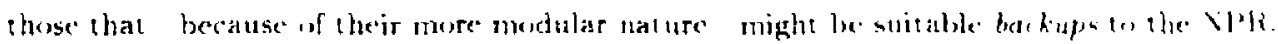
That is. souall units that can be developed and demenst rated at reasumable cont could provide.

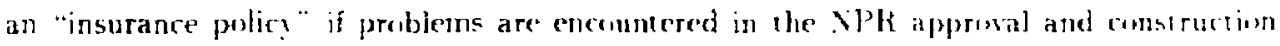
precess. Heplication of these small unit: 20 produce the needed anmat supply contd ibers proceed with prosen technolugy: minimum rapital and in "perating rost of the ultumer deplonnent might be considered secondary to the initial entlays recguired for verilication of the technology.

Five concepts based con technolugies under present or past deseropment or study in the Beam Rescarch and Magnetic Fusjon Prugram are assessed for theer putential fer tritum production. Ihree of the concepts are fusion bised and 1 wis are based un high eretergy beants. The three fusion-based concepts are listed below, along with their prenuncent or reviewrer:

- Linear Plasma [l.PJ - Fred Coensgen

- Jokamak Plasma (TP) - Kalph Moir

- Compar Turum Acceleratur (6"T H.AC E) Jim! Hammer

The two beam-bascot cuncepts are:

- Electron Limeas Accelerator (ELA) - Kon Hedike

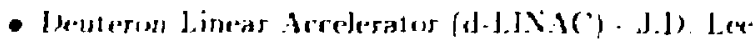

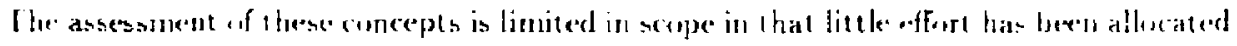

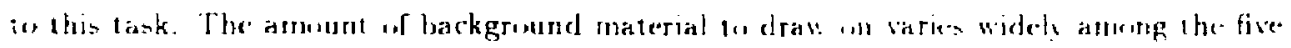
concepts. The whamak catse is supposted by a rather detajled study on its use at a tritum

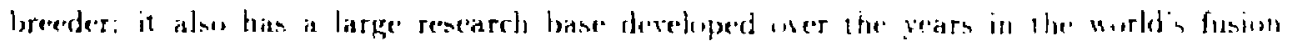




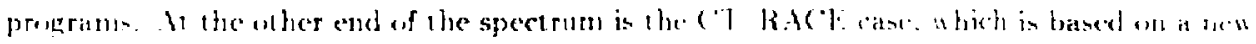

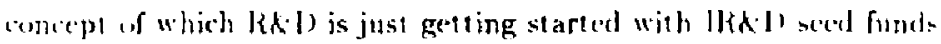

This white paper includes a section on each of the five concepten describing some of the

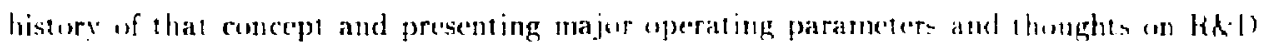
requiremests. The paper also includes a section that discusses blanket and targed kd-l) status and iswes. and it concludes with a summary section. 


\title{
LINEAR PLASMA-BASED TRITIUM PRODUCTION FACILITY
}

\author{
F.H. Coensgen, A.H. Futch, and A.W. Molvik
}

\section{Concept}

A schematic diagram of a $5 \mathrm{~kg}$, ye tritium breeder is shown in Fig. 1. I he sysem is simply long fullỵ imnized dense tritiun plasma column confined radially by a linear magneetic lielel.

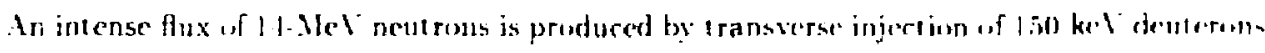
into the tritum plasma. Which is sufficienily dense to essentially stop all of the heams. I he trapped dewgerium ions collide with tritiun target jons. maintaing the [J. I fusion seactiou rate. The energetic ions are confined radially by the magnet ir field and longitudinally by

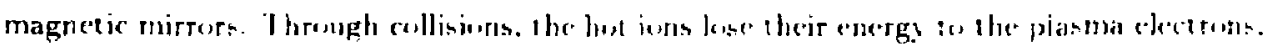
which in turn imize and heat the tritiun component and thus maintain the plasma target.

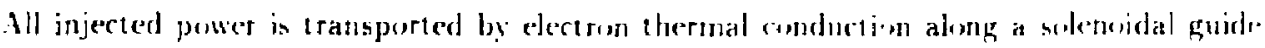

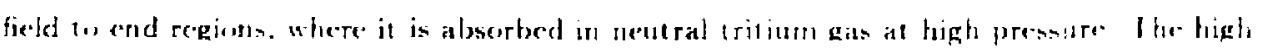

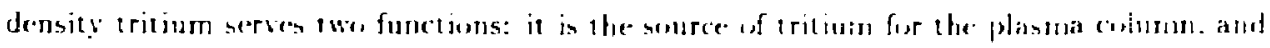

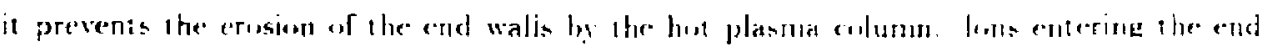

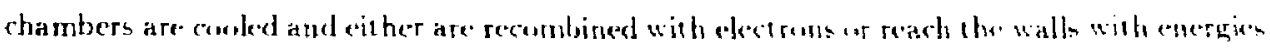

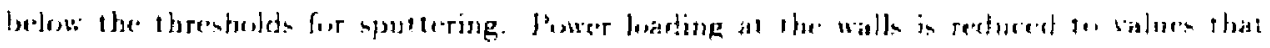

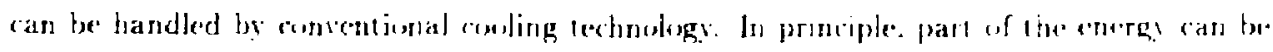

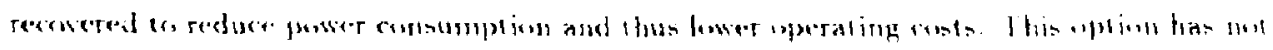

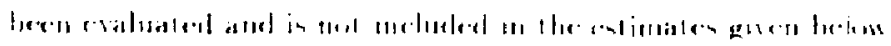

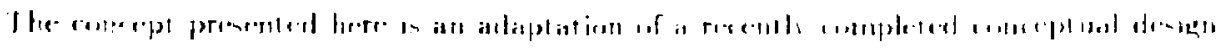




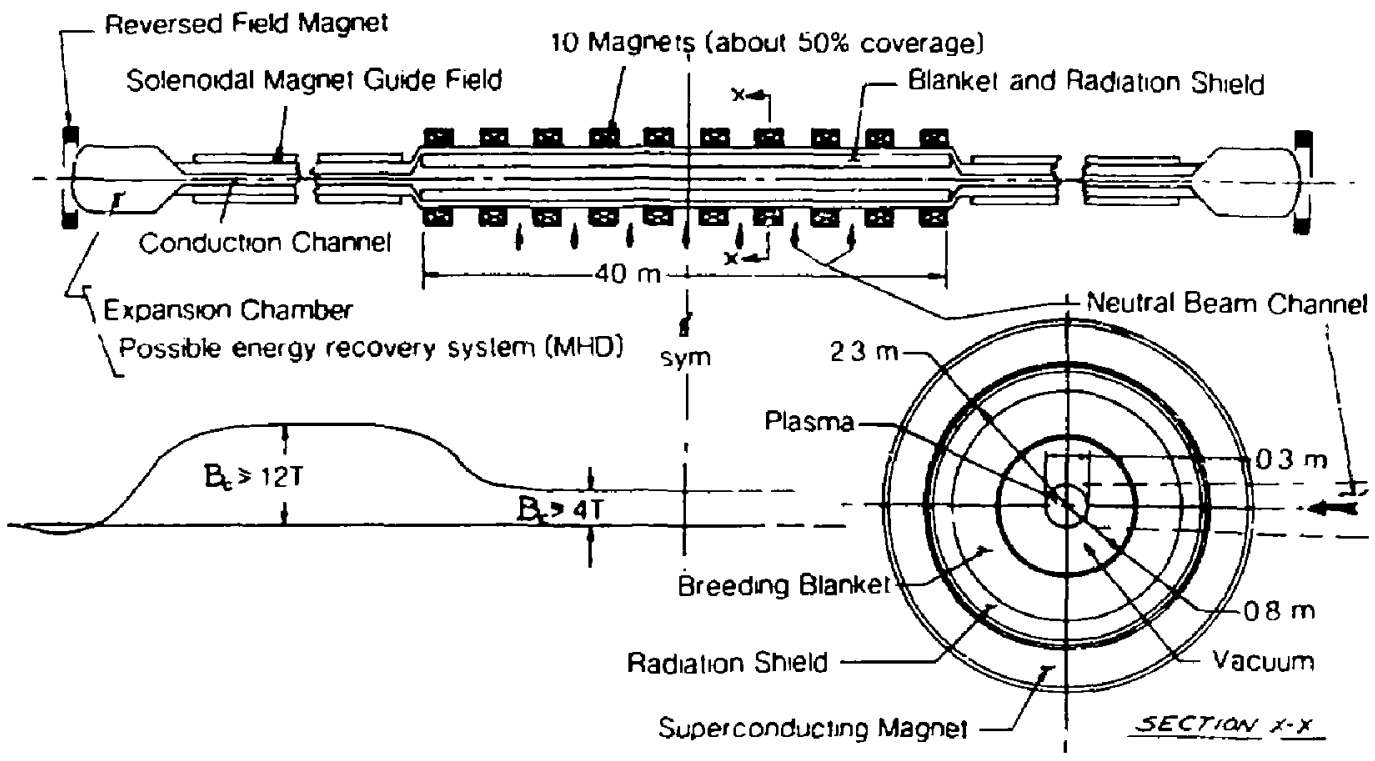

Figute 1: lincar Plasma. Based Jritum P'roduction Facility 


\begin{tabular}{|c|c|c|}
\hline Tutal length & $20010 \mathrm{ni}$ & 2011111 \\
\hline Heartion chamber lengtt. & lo1) & $f(1)+11$ \\
\hline lini size $\left(\mathrm{kg} \Gamma_{i} \mathrm{yr}\right)$ & 18.0 & .11 \\
\hline (apita) costs $\left(1 \times 10^{9} \mathrm{~s}\right)$ & 2.5 & $1.6^{12}$ \\
\hline liswer required (MMO) & 201010.0 & 11116103 \\
\hline ( ) perating and maintenance costs $\left(1 \times 19^{\text {fi }}:\right.$ ? & 100.0 & 310.0 \\
\hline Vumber of units to produce $5 \mathrm{~kg} \mathrm{~T} \mathrm{yr}$ & 0.28 & 1.0 \\
\hline$\varphi$ & $0 . \bar{i}$ & 10.3 \\
\hline
\end{tabular}

${ }^{a}$ Blanket and trutium recovers sustem not included.

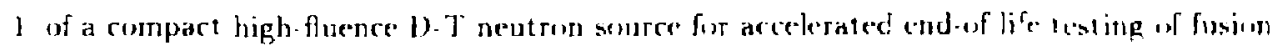
reactor materials. Nlehough this preliminary assessment serves to illustrate the main features of a linear fläsma-based triturn ?ereeder. it is not necessarily an optimized designt. We belteve that fooper demign chosers for the brecder application will certainly reduce custs. perbapn lng as much as a factor a, : wo. He also point out that ? the ration of insion pumer produced le power input to the plasma) increases with system length and that the cost per kg of tritiun decreases for lenger spstems with higher output (sec Table J). In earliev studies of linear

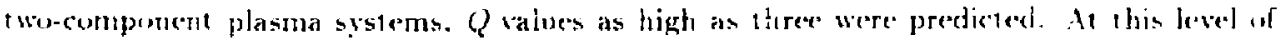

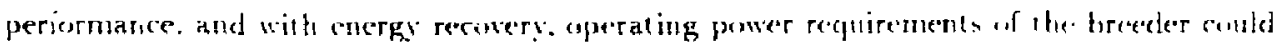
approach zero.

Similar valaces of $Q$ are ubtained in recent Soviel studies of long lincar mirror sustems. They discuss developonent of the'se systems for production af fissile fued and tritium.

\section{Physics and Technical Basis}

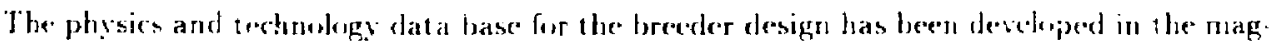
netic fusion program wer a considerable time span and has extemsive verification. I his data

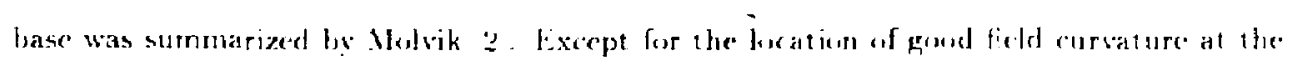

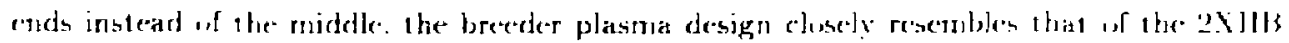

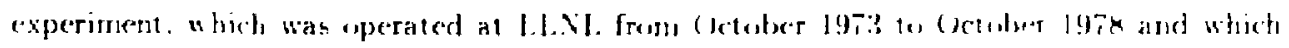


denumstrated stable operation of a two-component plasma 3. Totable anoung the achievements in that experiment was the demonstration of stable confinement of high- 3 plasmas using a mininum $H$ magnet in the central beam heated region. $t$ is the ratio of plasma energy density 10 magnet ic field energy density and high-3 is needed for economic operat ion of the breeder. Alsw, $2 X I I B$ experiments confirmed the theorctically derived conditions for ront rol of high-frequency fluct uations (i.e.. mirror mode mirroinstabilitics). Recent work on MIIll stability in axisymnet ric systems, such as the breeder design. is reported by Molvik ei al. I. Much of this work was carried out in a IS; ISSR collaborative effort on the Soviet Gas Iyramic Trap experiment at the Institute for Xuclear Physies. Xovosibirsk. LSSK. This experiment should est the ability of an axisymmetric system to reach high 3 with neutral beam iajection in the near future.

The duminam heat luss is the electron thermal conduction from the hot plasma core to the gas $t$ arget in each end cell. For a cylindrical plasma column, this power flow is given by

$$
\text { fow power }\left(4 \pi a^{2}, l_{c}\right) \int k d T_{c}
$$

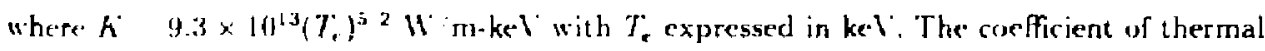
conductivity Was derived by Spitzer and Harm 5.. For a Gaussian radial profile. the f'sion powet is

$$
\text { fusion power } n_{h} n_{w}<\sigma r=E_{t} \pi u^{2} l_{h} \cdot ?
$$

where $n_{\text {, and }} n_{u}$ are the peak densities of the her and warm plasma. respectively: $l_{h}$ is the length of the plasma column occupriced by the hes ions: and a is the radial e. folding length of the plantra. Ois defined as

$$
\text { (y) fusion power How power } \left.1.47 \times 10^{24}<\sigma v>n_{u} \cdot n_{n_{t}} l_{r} l_{h} R\right) .\left(T_{\mathrm{c}}\right)^{7: 2}
$$

for cge unith except $T_{r}$ is expressed in ket. For a neutral beam efficicney of 36 to the tritium prudurticun rate becomes

$$
. W_{e}: \text { 12.7Qkg GH } y r
$$


All technologies needed for the tritjum breeder are within the state of the art. "We litl kel neutral beams will be demonstrated on JF.'T in the fpring of 1989 for a duration of 10-20 s. All components are essentially at steady statc. A longer lived cathode is desirable since present filaments are estimated to have a 2 werk lifetine in stcady-stabe operatint. Superconduating magnets of I2-T fields were demonstrated during MFTF acreplance tosts. The blanket technolugy is based on existing designs.

\section{Development}

We bolice that a tritium breeder based on a lineia plasma system could be an alternati e or backup for a production facilit: and ue recommend it serious design etfort lee initiated at this time. Ansuming favorable M!HI) stability can be proven in an axisymmetric linear system. we can build upun existing physies and technolugg facilijes to develup a safe. re. liable. continuously operating production facility as soon as possible, by mearm of a test sertion of a full-sized breede- constructed and tested following the design study. This test section would first be run using hydrogen to averid ewetron radiation and activation problems during development of continuous operation of neut ral-bean systerns. power remonal and ior erergy. recovery. and remote-controlled operation and maintenance. All safeiy asperts of the facility womld also be perfected and demonstrated in the hedregen aperation phases. (Jnce reliabilits and safrig are demonst rated, the gest bection womld be operated as a tritimm breeder to perfect blankel technology and tritium extraclinn. Based on utir oust analysin of

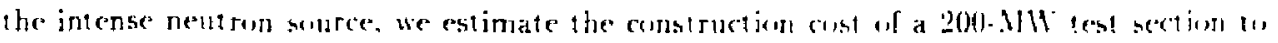
be approxinately $\$ 250,11$.

In a mere comerative approsch to develop the breder. the integrated phisics design

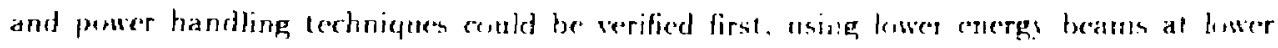

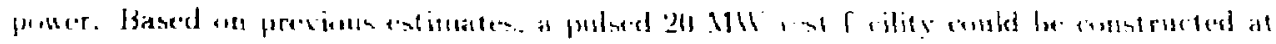

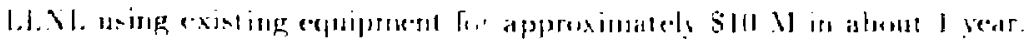




\section{Crst Basis}

To est imaie const ruction and operating costs, we note that th: size of the system is essentially proportional to the raquired power, which is estimated as ciatlined bolow. Costs are then obtained by scaling our cstimates for the incense neutron source. For the 5 -kg/yr facility. the estimated construction cost is $\$ 1.6 \mathrm{~B}$ withoul tritium breding blankets of extraction Facilities. Operating costs are strongly dependent on power costs and energy recovery.

\section{References}

1. F.H. Coensgen, J'.. Casper, ... C. Correll, C.C. Damm, A.H. Futch, B.G. Logan, A.W. Molvik. K.H. Bulner, "A D.T Veutron Source for Fusion Materials Testing," Lawrence Livernore $\mathrm{X}$. ional Laboratory, Livermore. CA. LCRI,-97280, Hev. 1 (1987).

2. A.K. Molvik, "Summary of Mirror Lxperiments Relevant to Beam-Plasma Veutron Sourcia." Lawrence Livermore National Laboratory, Livermore. ('A, L'C'II)-21532 (1988).

3 IV.C. Turner. J.F. Claliser, F.H. Coensgen, D.L. C'orrell, W.J. C'ummins, K.P. Frejs, K.K. Geodman, A.L. Hunt, T.B. Kaiser, (B.M. Melin, W.L. Kexsen, T.C'. Simonen, and B.11: Stallard. Nucl. Fusion 19, :011 (1979).

4. T.A. C"axper, A.H. Malvik. P. Bagryartsky, et al., "Fluctuation Measurements Study of the MH1) Stability of the Gas Dynamic Trap." presented at the 1.3th Annual Meeting, Jjyjisin of Plasma Physics, Hollywond, Fl, Lawrence Livermore Vational laboratory, livermore. ('A. l'('KL- 49587 (1988).

5 1. Spitzer and J. Harm. Phys. Kev. 89, 977 (1953). 


\title{
A DRIVEN TOK/ MAK FOR TRITIUM PRODUCTION
}

\author{
Ralph Moir
}

The potential for producing tritium from fusion neut roms absorbed in lithium is explured baced on a study of a driven tokamak 1,2 . A steady-state neutral-beami-driven tokamak based on the present tokamak at Princeten, called TFTR, is predicted to generate about

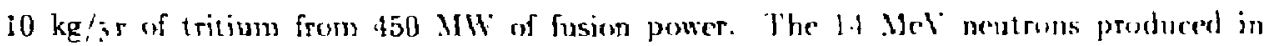
the fusion reaction are multiplied in the berylium blanket. and tritium is proxluced in the Li-Al alloy blanke. The blanket structure is made of aluminum and is watgrecoled at a temperature of less than $100^{\circ} \mathrm{C}$. Figure 2 shows the productien reactor and Fig. 3 compares the reacting plasma and magnets of the production reactor with those of JFTK. shown as an overlay for comparison.

A set of paramelers for the production reactor called the Nagnetic Fusiur l'roduction Reactor (MFPR) is given in " "abl 2. with TFTK "supershot" parameters achieved shown for comparison. The parameters are scaled up by a mudest anuout and are mo very speculative. but as we have learned in the magnetic fusion program. pregress dessn : come casily! 'T he

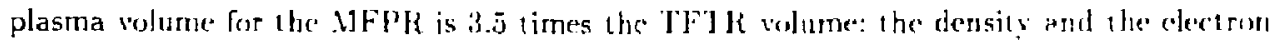
temperature are both iwice that of TFJ

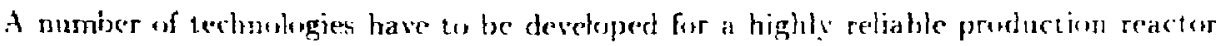
based on the tokamak. Among these ase diverturs. magnets. remoule handling ecuipument. blantets, and negative ion beams. The ongoing wortdwide fusiun programs will develop all

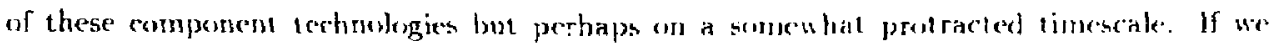




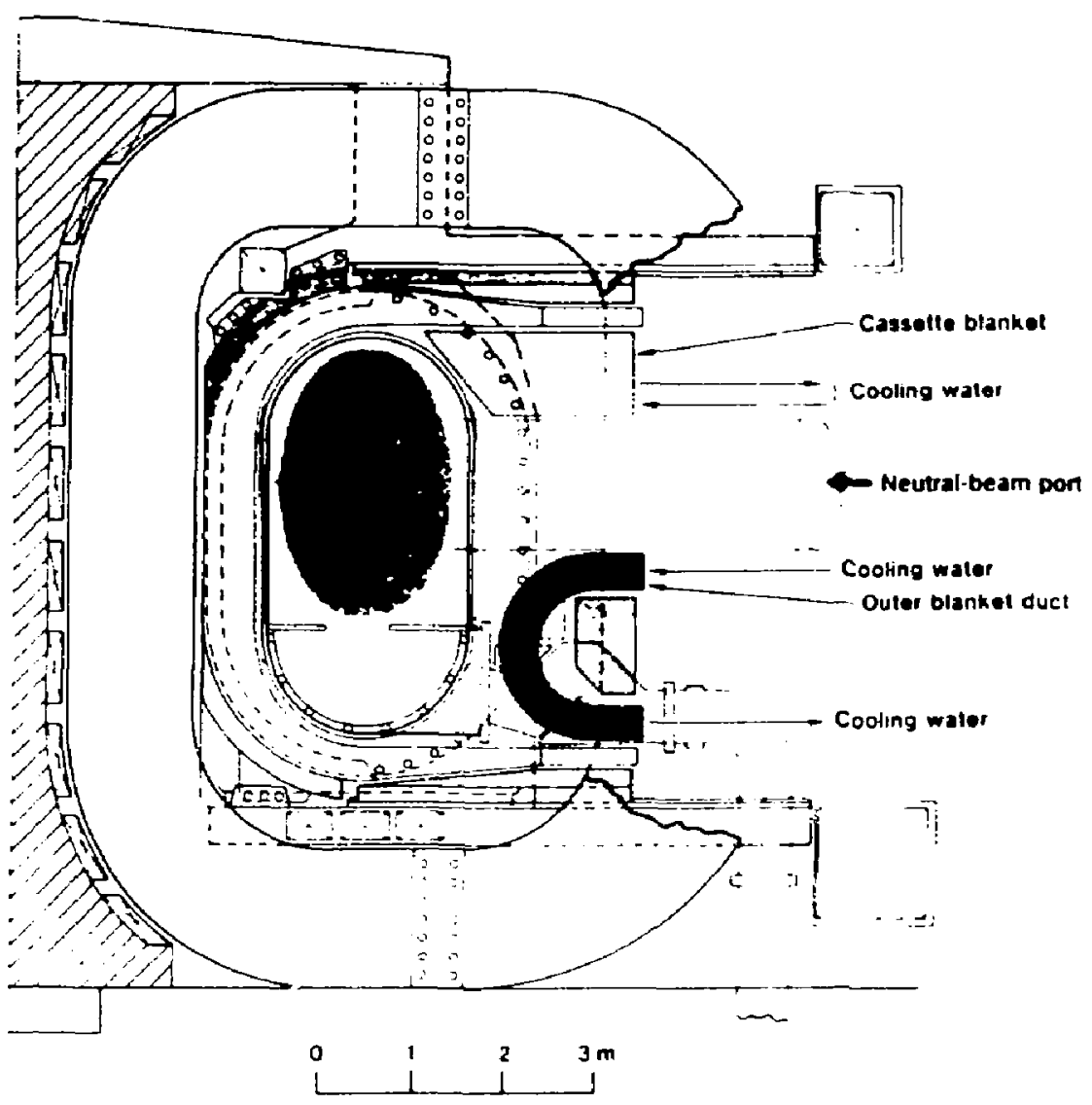

Figure 2: Evaluation view of the tukanak WFJK based on supershus-like plasma. 


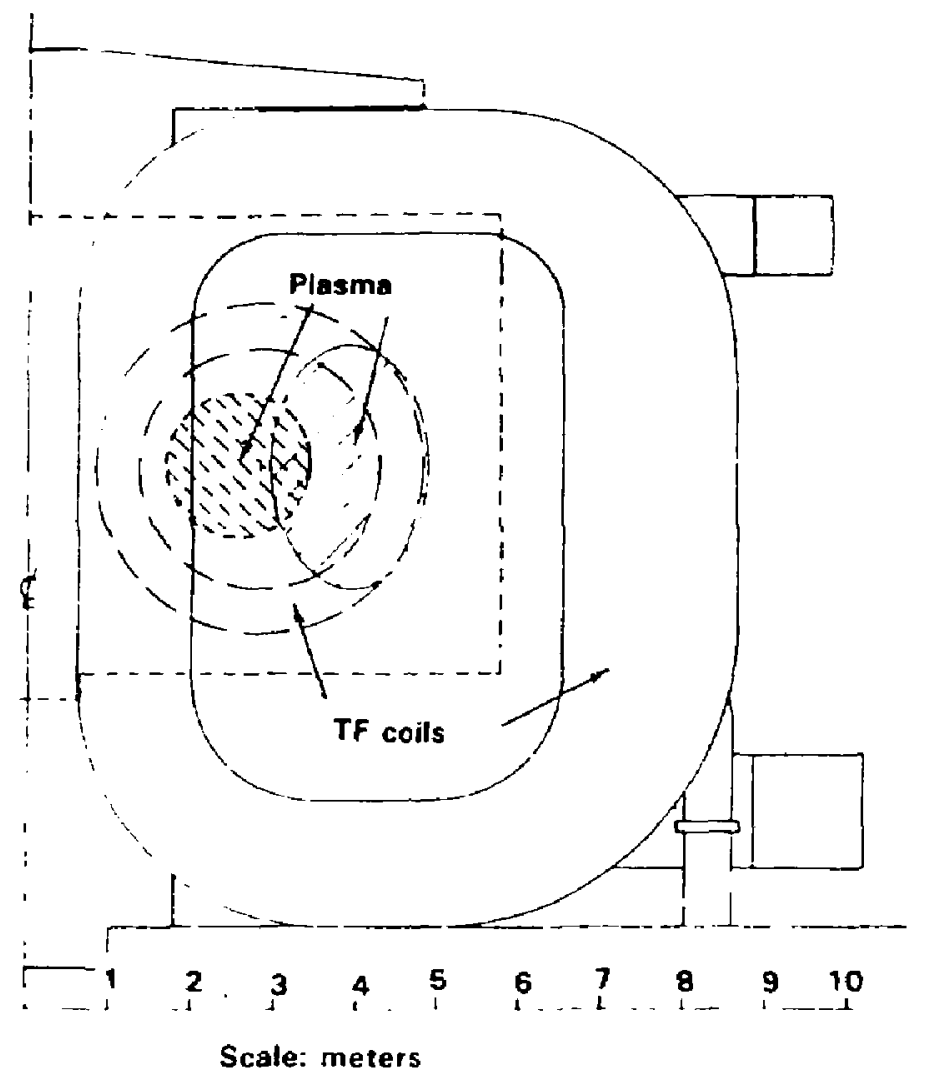

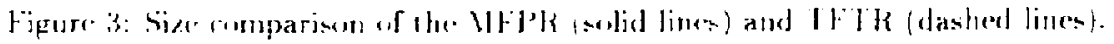


lable 2: Tokamak syatoll parametcrs.

\begin{tabular}{|c|c|c|}
\hline & & He:s Ifll \\
\hline & llkpk & Sifporshoits \\
\hline Plasma majur radius & $3.9 \mathrm{~m}$ & $2.5 \mathrm{~m}$ \\
\hline Plasma minor radius & $11.5 \mathrm{~m}$ & $0.8 .3 \mathrm{mII}$ \\
\hline Piasma elongation & 1.5 & 1.0 \\
\hline Maximum field at IF coils & $9.5 \mathrm{~T}$ & $9.6 \%$ \\
\hline Maximum field un plasma axis & $5.01 \mathrm{~T}$ & 5.21 \\
\hline Magnetic flux swing from solentrid & 13116 & $1314 b$ \\
\hline Veutral bearn power. [\}$^{c}$ & 100.1111 & 15.111 \\
\hline Veutral beam power. " $]^{\circ}$ & 50111 & 151114 \\
\hline Ventral beam energ: $\mathrm{I}^{\circ}$ & $250 \mathrm{kel}$ & $110 \mathrm{kol}$ \\
\hline Veutral beam encrgy. $\mathrm{T}=$ & $3.10 \mathrm{kel}$ & l20 ke'l \\
\hline Plasma current & 5.511 .1 & $1.6 .11 \mathrm{~A}$ \\
\hline Pulse length & Siendy-state & 2 \\
\hline Filectron density (peak) & $1.65 \times 10^{14}$ & $8 \times 10^{3}$ \\
\hline E.lectron temperature (poak) & $20 \mathrm{ke} \cdot \mathrm{l}$ & $9 \mathrm{kc} \cdot \mathrm{l}$ \\
\hline lonl lemperature (peak) & $35 \mathrm{ke}-\mathrm{l}$ & $32 \mathrm{ke} \cdot \mathrm{l}$ \\
\hline Violume-als. tolal beta & $5 \because \pi$ & $1.5 \%$ \\
\hline Frac of total pressure in hot ioms & $1 \cdot 3$ & 1,3 \\
\hline Energy confinement line. $T$. & $0.35 \mathrm{~s}$ & $0.17 *$ \\
\hline$i(0) \times \div\left(\mathrm{cm}^{3} \mathrm{~s}\right)$ & $5.5 \times 11^{13}$ & $1.3 \times 10^{1.3}$ \\
\hline$i_{i+11}$ & $1 . \overline{1}$ & 2.3 \\
\hline & & $\Delta p+d, d$ \\
\hline Fusion gain. () & 3.0 & 1.0 \\
\hline Tintal fusiun power & 150111 & 30114 \\
\hline Veutron wall hading ( $\left.1111^{\circ} \mathrm{m}^{2}\right)$ & & \\
\hline Spatia!ly averaged & 1.4 & 0.20 \\
\hline At coutherard nidplanc & 1.65 & 0.25 \\
\hline
\end{tabular}


Table 3: Capital Cost and (innstrurtion.

\begin{tabular}{|c|c|c|}
\hline & Timer & (19825) \\
\hline Iresign ironstruct & 6 yers & $51.9 \mathrm{H}$ \\
\hline Operace & $2 y r s$ & \\
\hline 'pgrade' & 2 yrs & 0.7 \\
\hline Tritium processing plant & & 0.1 \\
\hline
\end{tabular}

were to design and build the tokamak starting 2 years from now. We coukd not wait fir many of the results that would naturally conne along 10 gears later. 1 he driven lokamak in less demanding of these technokigies and not rery expersive and could be undertaken at a fraction (perhaps only 20\%) of the $\$ 2.2$ B construction cost. The neutral beams 100 .11W

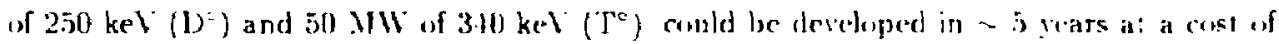
$-\$ 10 \mathrm{N1}$

The power requirements are 560 .1We. of which 270 .1WWe is for the neutral beame and 220 .1We is for the coroidal field coils. The study 3 was done more than 8 gears agu. Xiow superconducting magnets may be appropriate, in which case the power cousumplion comess

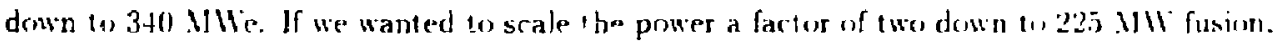
the beam power would be reduced by 135.11 We. bringing the 101 al power consumption dinn to 205 . Whe for $5 \mathrm{~kg} / \mathrm{yr}$ of tritjum production.

Our idea is to design (2yr) and bujld (t. yr) the lokamak and to uperale it for a periud of perhaps 2 years. after which time we assume a 2-year upgrade of compunente lu a state of high reliability. This is illustrated in Table 3.

A production reactor could be sperational 10 years after a clear decision to procered. A fair amount of development could proceed in paralled. The upgrade, which would include. the reliable breeding blankets and all highly reliable components such as long lived neeutral

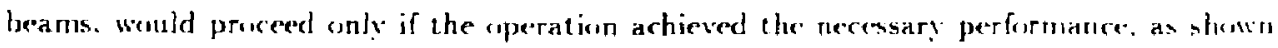
in Table 2. The operating cost has been cstimated and is shown in Tabje 1 


\begin{tabular}{|c|c|}
\hline Heactor OX:H & $\$ 311.11 .4 r$ \\
\hline l'rucess pliant & in \\
\hline Blanket replare'ment & 20 \\
\hline Fikectricity $\left(50.045 \mathrm{kll} \mathrm{h}_{1}\right)$ & $\begin{array}{l}\$ 95.11 / y \\
\$ 185.11 \quad \mathrm{r}\end{array}$ \\
\hline
\end{tabular}

The Academy of Science and lingineering conducted a stude of the tokamak as a tritium producer 3. Their conchusiss is reproduced here:

Becanse the iritiun breeding fusion reactor offers promising featutes of yicld. crist. and tectuncolengl. officials in the $I . S$. Depart meent of Energ. concerned with the capability and security of tritium production should undertake a program that analyzes and pericdically reassesses the roncept. including design studies, experimentation. and esaluation as fusien develepment proreeds.

\section{References}

1 H.H. Campbell. S.A. Freije. I).L. Jassby J.J. Iae. J.B. Mitchell. R.M. Moir, and II.S. Xet. "Magnetic fusion Prumuction Keactor." J. Fusion Fnerg: special issues. 5. So. I (1)ec. 1986) and 6. No. I (Narch 1985).

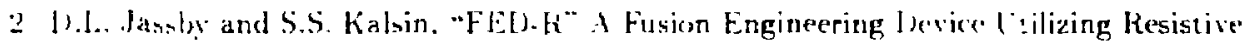

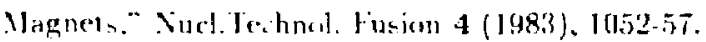

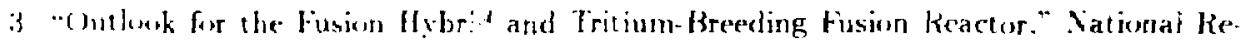
search (iuncil. Juhn Simpson. ('hairman (1987). 


\title{
COMPACT TORUS ACCELERATOR CONCEPT
}

\author{
Jim Hammer
}

The compare kurus acceleratur $l$ is a device that acceletates magmetisally conitined

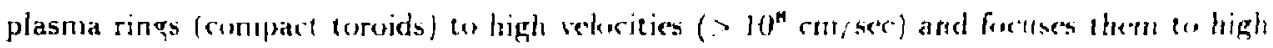

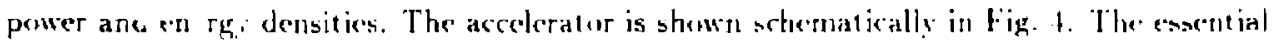
elerents are a magnetized roaxial plasma gun for forming the compact torus, a compres. sins iacceleration stage where the torum is confined between conducting coaxial elect rorlen and accelerated by $\mathrm{J} \times \mathrm{B}$ inses. a forusing stage. and a converter where depunition of the compact torus kisetic energy results in neutron production. The coaxial gun and accelerator have separate power supplies (usually fast capacitor banks). The accelerator is distinguished from other 1ypes of plasma acceleraturs by the magnetic confinement of the aicclierated piasma. This allows acceleration over many ring diameters to high velu ities and high kinetic energies

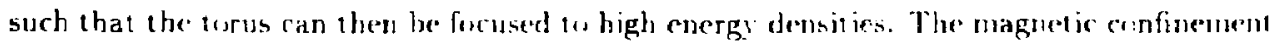
of the accelerated plasma is alsu an ardwantage in the chove of co neasion schemes for neutrun production.

For the purposes of scoping this concept. we will assume the a cornserter of the .llc' (magnetically-insulated inertial confinement fuswem) ? lype is empleped. An acceleralor

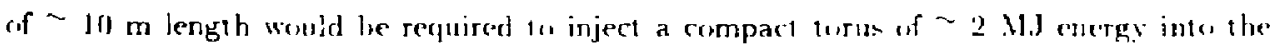

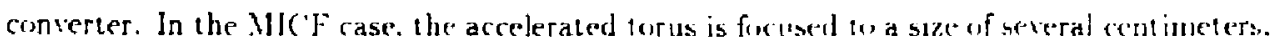
a magnetic field strength of a few megagauss. and injected infu a ftuid- walled chatuber / r.g..

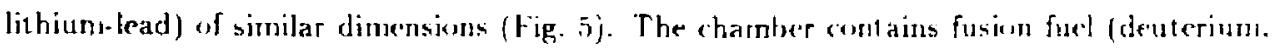

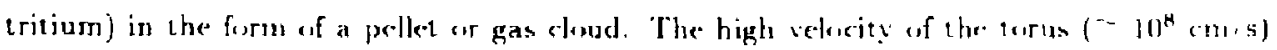




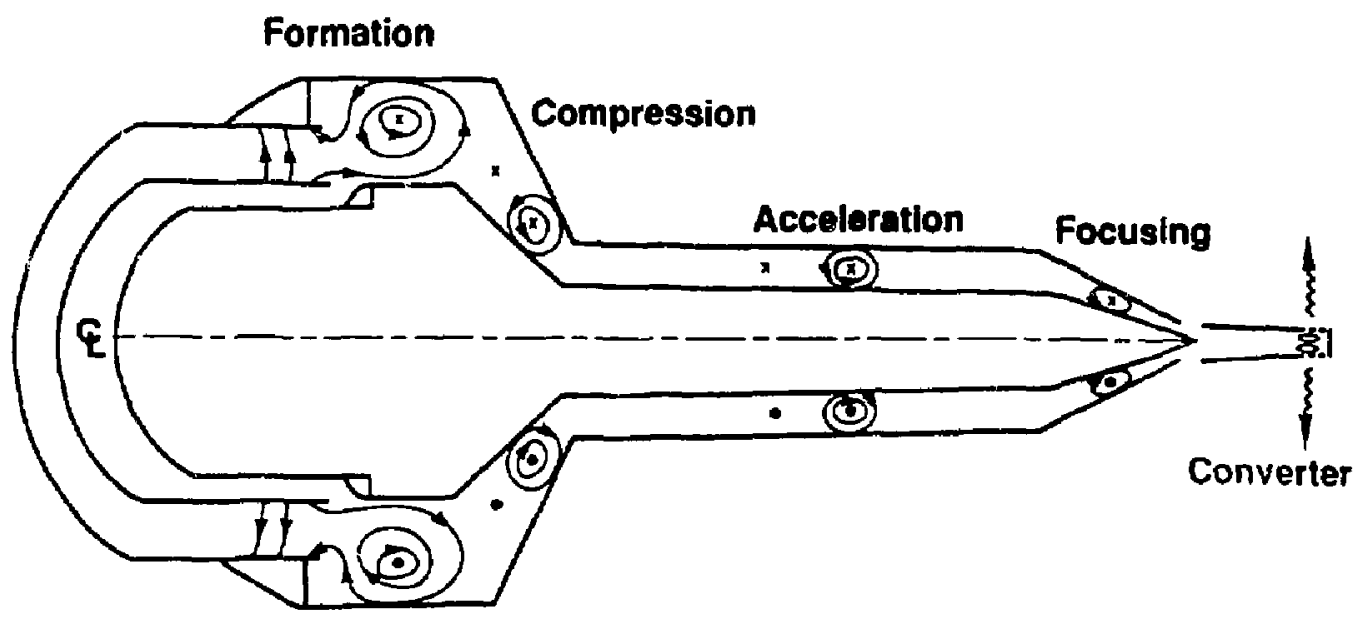

figure 1: fimpact torus neutrongeneration follows the four ph: thes of acceleration. 


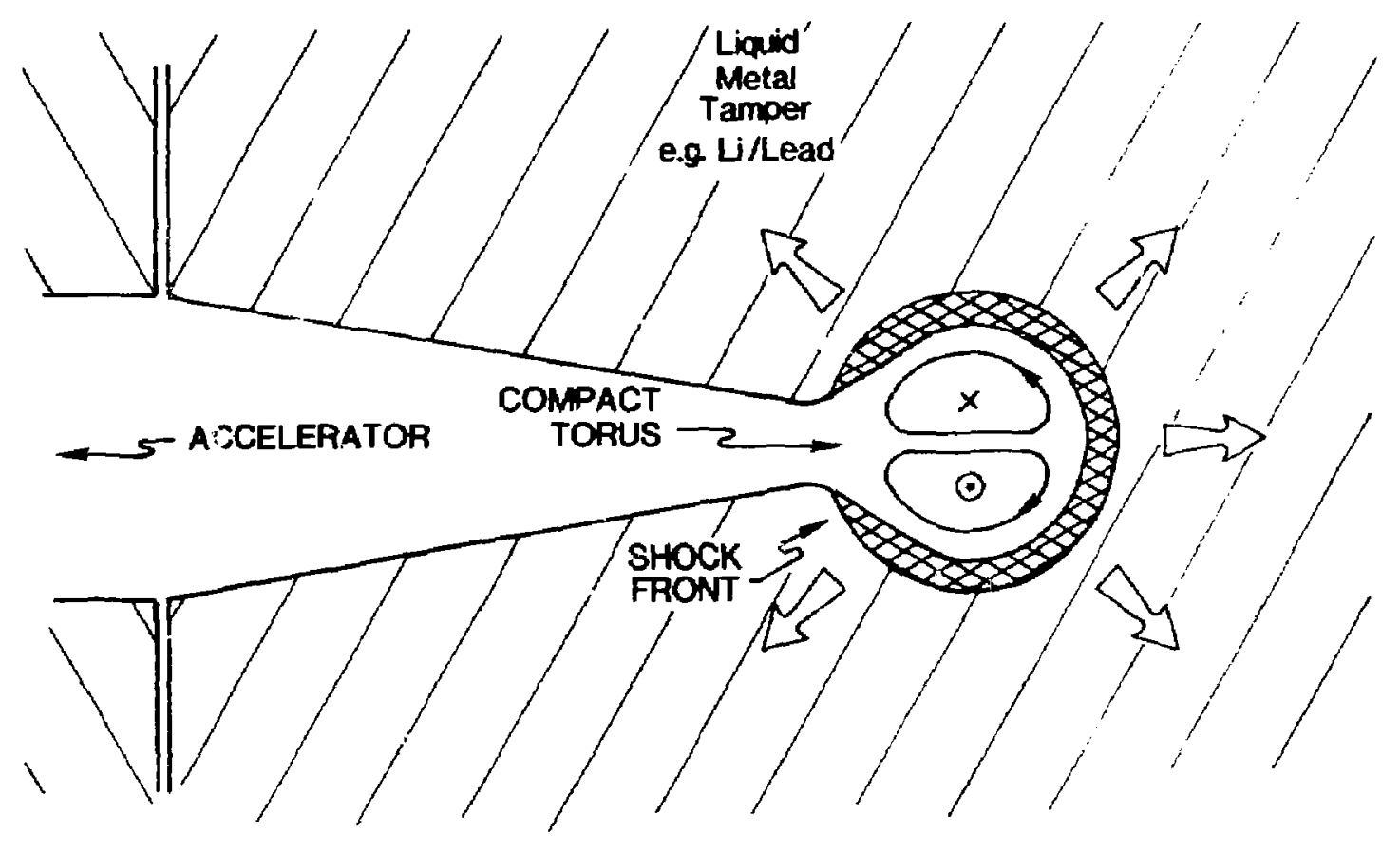

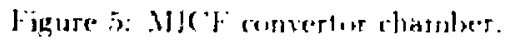




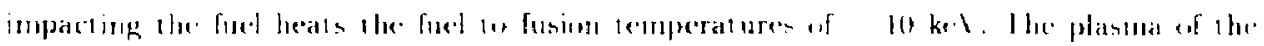
injerted torus could also be deuterium and or tritium. The mat:net ic fietd suppresses elect ron heat less to the wall se that confinement of the hos plasma and thermumaclear neutron preduction is limited by the inerlial disassembly af the liquid wall (-turn $\sim$ les). The degree of magnetic confinement reguired is guile modest since the burn time is less than the Bohm confinement time. 1 ' shortest trancport time usually applicable 10 a magneticalty. confined plasna. Because of the simple germeetry (ner coils. etc.). it sheuld be pussible to almost completely surround the impact chamber with breeding material flithium with a berylliur: netutun multiplier) such that a breeding ratio of unity is approached: i.t.. 1 wo tritons produced for cach trikon consumed in a fusion reaction.

'T he compat torus accelerator concept has been demonstrated at the $2(1-40 \mathrm{~kJ}$ level with ring velucitien $<3 \times 30^{8} \mathrm{~cm} / \mathrm{s}$ on the RAC'E 3 . (Ring AC'celeration Fxperiment) device at I.L.is. Tha concept evoused from magnetic fusion studies of the spherumak-type of cumpact torus at ILXI. The earlier experiment (Beta 11) it alsu used a magnetized roaxial plasma gun (a Marshall-1ype gun with an embedded $B_{r} . B_{z}$ field from a sulenoidal magnet) io form the tor t.. "Which was subsequently trapped in a fixx-conserving met al shell for confinement studien. The compact torus fiedd structure is characterized by a dipolo-like $B_{r}$. $B$ : field ancompassing an azimuthal $B_{\theta}$ field, in many respects similar to the tokamak magnctic confinenent device. The itelds afe produced by currents flowing within the plasma and image currents in nearby conductors. so the compact torus is mot tied fo an external coil structure and may be tramblated axially. The "portability" of the te us and its long lofetime (100"s af 1s) led laturally to the corcept of an arcelerator employing the torus to confine plasma cover long lormw distances, allowing higher velocities ant' wltimately higher power energy densities than can be otherwise achieved. A tariety of applications are concejved for the device. inchading an injector to fuel or drive current in tokamaks, an intense pulsed $x$-ray source. a high-prwer microwase generator. a fast-opening switch for pulsed power applications $\mathbf{a}$. a 


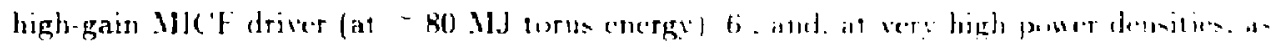
an ion beam driver for inertial confinement fusion $T$

\section{Projected Performance Parameters}

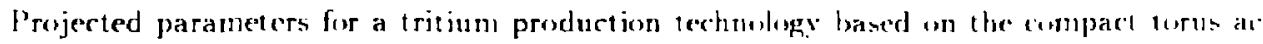
celerator are shomn in Table 5 . The product torn paraneters shown in Table is correspond we an accelerator with the parameters shown in Table $f$.

\begin{tabular}{|c|c|c|}
\hline Capacily kg yr & $\begin{array}{l}\text { Table s: } \\
\text { E.leciric l'suse hecupired } \\
\text { per unit (cill) }\end{array}$ & $\begin{array}{l}\text { Direest ('ust } \\
\text { per unit (S B) }\end{array}$ \\
\hline 0.027 & $0.0066 \mathrm{~T}$ & $<0.1113^{\prime \prime}$ \\
\hline $\pm l$ lnits fr.r $5 \mathrm{~kg}$ tritium & $\mathrm{kg}$-tritium per ( & 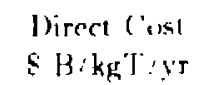 \\
\hline $265^{b}$ & 1 & $<11.699^{\prime \prime}$ \\
\hline
\end{tabular}

There are numerous uncertaint ies in the projections shown in Tables a and fo. The physiss

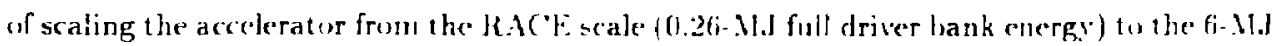
level and to the requisite energy densities have set 10 be denonst rated. While the neutron conversion scheme places modest demands on the magnet ic confinement propertien of he

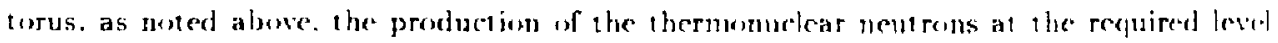
must also be demonstrated.

\begin{tabular}{|c|c|}
\hline I river bank energy & $6.11 . J$ \\
\hline ('ompact torus energy (kinetic $k$ magnet ic & 2. M.J \\
\hline Compact torus relucity & $=10^{4} \mathrm{~cm}$. \\
\hline livlume of focused torus iconverter chamber & 27 cr \\
\hline Accelerator length & $-10 \mathrm{~m}$ \\
\hline Reps rate & $1 \mathrm{~h} z$ \\
\hline
\end{tabular}

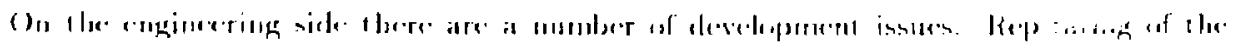




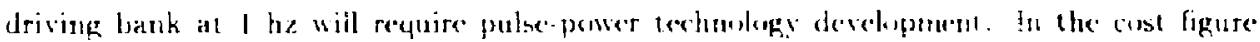
included in lable 5 . the driving bank was costed at 52 joule to allow for the estimated increase in asts due to rep-rating (non-rep-rated banks of the recpuisite type are typically S0.j(0.51, joule). The driving bank is assumed to dominate the cest. Surtival of arceleratur elecerodes for $=10^{\circ}$ pulses is also ra development insule.

Since the scheme emplog's cienterium-tritium fusion at low burn-up fraction. a high tritium recycling efficiency will be neceswary. Alsu, a comserter thamber fblanket design that can withstand the pulsed loading must be designed.

The unique feature of the concept which may offset the mant technical uncertainties is the high degree of modularity. This weold allow construction of a full-scale prototype unit at low cust (few $\times \$ 10.11$ for the accelerator and driver bank), given success of the research and development program. The small size of the unit should also speed the rese'arch phase. The existing prugram plan for compact torus accelerator research at LLXL calls for 2 additional years of experimentation on $K A C E$ at a level of $\$ 2.5 .1 /$ year, followed by a 3. rear researdh program on a 2-19.J KACF. upgrade at \$3.5N/year. The RACF upgrade accelerator is projected to produce compact energies and power densities within a fartor of three of the requirements for a iritium produrtion module as outlined in Tables 5 and 6 . The phissic: research phase could be accelorated by werlapping the upgrade construction with

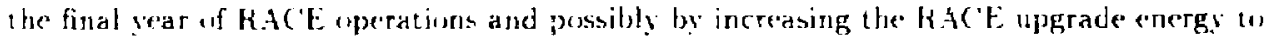
the 6-Mll level. A developmem program studying driver bank rep-rating issues and design of the converter chamber would need to be carried out in parallel to allow construction of a pronotype unit in the mid $19990^{\circ} \mathrm{s}$.

\section{References}

1 (:.11. Hartman and J.H. Hammer. Jhys. Hex. Jetl. 48, 929 (1982).

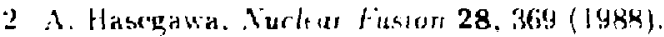




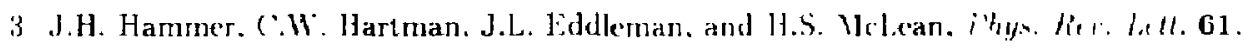
$2843(1988)$.

If H.C. Turner. et al.. Phys. Fiuds 26. 1965 (1983).

5 C.W. Hartman and J.H. Hammer, Lawrence Livermore Valiumal laburatery Hepurt LLL-PROP-19i, 1984.

6. B.G. Logan. private communication.

F. C.W. Hartman. J.L. Eddleman. J.H. Hammer. and D.L. Meeker, in proceedings of the fth ]nternational Conference on Emerging Nuclear Systems, Nadrid. Spain. ] g8fi (World Scientific. Singapore, 1986) p. 158. 


\title{
ELECTRON LINEAR ACCELERATOR PRODUCTION OF TRITIUM
}

\author{
Roy Hedtke
}

\section{Basic Concept}

('isrent J)epartment of I)efense (I)(JJ)) programs are funding the develepment of very highaverage-poner electron induction accelerators. For this reason, it is appropriate to examine the sat ential of this technolugy for trituim production.

The basic concept is simple. Electrons are injocted into the accelerator vith a given amunt of energ. (on the sorder of $3 \mathrm{Met}$ ) and accelerated through induction cells to whatever end energy is desired. The current design of the induction cell allows a gap potential of 100 w $300 \mathrm{kl}$ per cell. When the electron bean has been arceletated 10 its end energy, it must be transported somewhere, in this rase tu the target area. In the target area the beam passes 1 hrough several layeres of difieriı g materials (tungster) Lo produce first bremsstrahlung radialien and then a stream of motrons which gets multiplied in berpllium; finally, the nentroms are directed onw a lithium target 10 produce a triton and an additional neutron. ('onceptually. the idea is relatively simple. Figuse 6 contains a sketch of this idea.

\section{Historical Evolution}

Inetelumentally: the electron accelerator has received much recent attention (late 1970\% (n) at LLCI. as a result of DARPA's funding of the ('harged Particle Beam Program. The successes at the Advanced Iest Accelerator and other test beds led to the Free Electron Laser (FEl.) Jrogram. 'These programs stressed high-average-puwer. high-current, pulsed 


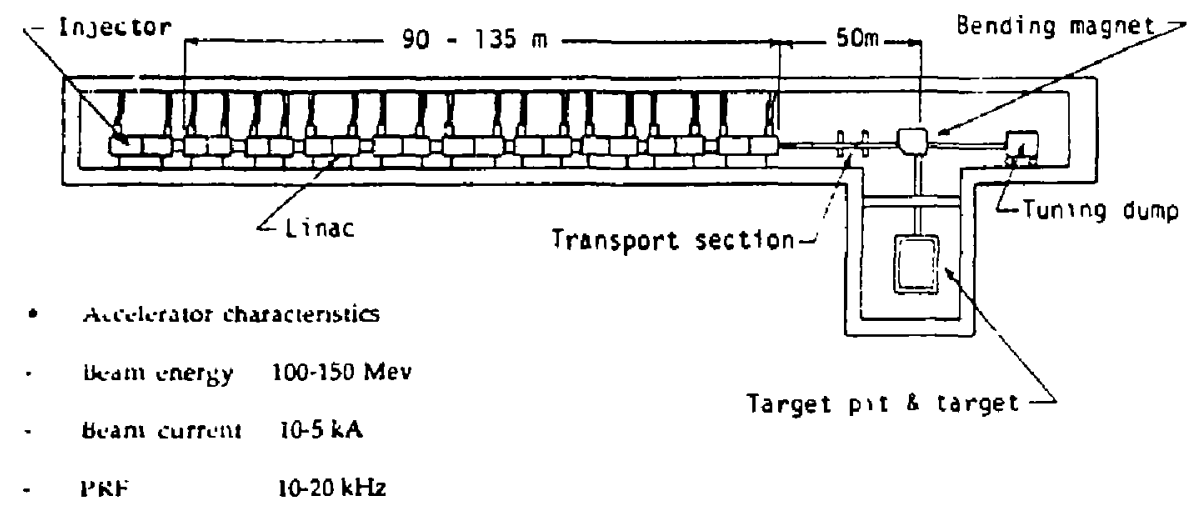

Figure 6: Conceptual drawing of electron linear accelerator.

accelerators for weapons applications. The typical accelerator envisioned for the production of tritium will necessarily be a high-average-power $\mathrm{cw}$ machine. The results of these programs have a synergistic effect on any efforts to develop a machine fur tritium production. In spite of many reports on electron linacs, our research indicates that electron acceleraturs have not previous]y been seriously considered for proúcing tritium. except as they may apply to some fusion prugrams. Litule or no developmental work has been rompleted in the area of targets for tritium production since the mid 1970's. The bulk of that work for:ssed on the use of fertile and other high- $Z$ materials in produce copious amounts of neut rons. The least developed facet of this concept is the target portion.

\section{Major References}

1. Accelerator spreadsheet developed by J.H. VanSant to determine acrelerator costs and operating parameters.

2. C.M. Ian Atta. J.D. Lee. and W. Heckrotte, The Electromuctear Comersion of Firtile to Ftssile Mat rol. Lawrence Livermore Sational Laboratory. Livermore, ('A. I'C'RI. $52144 .(1976)$. 


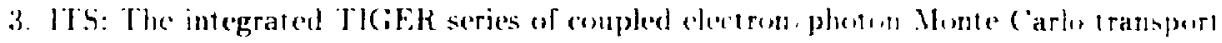
rodes. Sandia Nalional Laboratory:

4. IAE. Technical Report Series Xo. 188. Kadialogical Lalets Aspests of the Opera tiun of Electron Line'zr Accelerators. M.I'. Swanson, I979, and his artick: "Inproved (alculation of Photoneutron Yields Released by Incident Electrons." (1979).

5. liscussions with key laboratory persnonel and other library resenrch.

\section{Performance Parameters}

The electron linear induction accelerator has nominal operating characteristics of 100 to 150 Mel. a beam current of 10 to $5 \mathrm{k} h$, a pulse width of $50 \mathrm{~ns}$, and a repetition frequency uf 10 to $20 \mathrm{kllz}$. These characteristirs do not represent an optimized accelerator design. Much study would have to go into such a design before it could be considered optimized. These parameters correspond to an accelerator with an average power of 500 to $750 \mathrm{MIH}$. That is approxinately two to three times greater than the averag: pewer of the accelerator fur the FlEL sistem at White Sards Missile Kange (MSML). New Mexicu. With operating rharacteristics such at these, one accelerator will produce approximately foug of trition per vear. assuming a tungsten target fur neutron production whih a slighl neeutron multiplication.

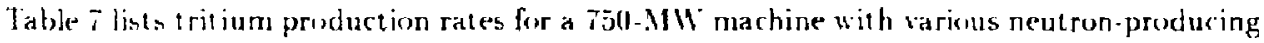
targets and neut ron multiplication factors. Multiplication factors of two are reasonable, and a factor of five may be achievable in beryllinm. Research indicates thal neutron multiplication would be at least an crder of magnitude higher in a fissile material such as uranium. The remaining key performance parameters. for the baseline case. are comtained in Table 8 . The paraneeters listed in the table are sery sensitive to average puwer arul multiplication factur. The assumpliens made alout a plant's reliability will also drastically affert entimates of iritium production. The baseline case is based an a single point design, rather than a broas 
Table $i$ : Tritinm production rates for varions larget matcrials Veutron Multiplication Fartur

\begin{tabular}{|c|c|c|c|c|}
\hline \multirow{2}{*}{$\begin{array}{l}\text { Target Mlaterial } \\
\text { iranium }\end{array}$} & $\begin{array}{r}(g-T / 2 t) \\
\text { Yield } \\
\end{array}$ & \multicolumn{3}{|c|}{$\begin{array}{l}2 \quad 3 \\
\text { (assumes l y } \\
\text { (of cw operation) }\end{array}$} \\
\hline & 411 & 82.1 & 1236 & 16.17 \\
\hline Tungsten & 279 & 5.59 & $8: 38$ & 1117 \\
\hline Aluminum & 69 & 37 & 206 & 275 \\
\hline Beryllium & 42 & 83 & 123 & 16 \\
\hline
\end{tabular}

study of the problem. An optimization of the accelerator configuration would undoubtedly result in a machise with different operating parameters.

\section{WSMR Machine: Performance}

An interest was expressed in the amount of tritium that the WSMll device could produce in 1 rear. I'sing the stated pulse format, assuming wo could use this muber of pulses per day: for 200 operating days per yeat, we would produce $0.022 \mathrm{~g}$ T' Year. I makes no difference how the 630.000 pulses are used. for 1 m) seconds at full PKF or whether the rep rate is lonered and the pulses expended wer a period of 6 hours. The fact that the 11 S 11 k device is pulsed, plus its lower average power. accounts for its small armount of 1 ritium producrion.

\section{Level of Design Optimism}

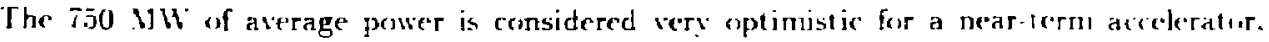
esperially considering that the acceleratur would have to run rontinuously. The Irmy ma chine at MSMIR is designed to operate in a pulsed mode for no, more than I00 secomds. Muat accelerator experts would agree that operating comtinuously at this high-average prewer with

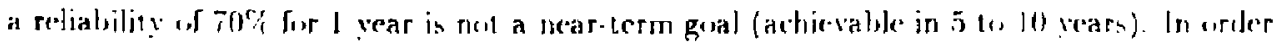
tu produce sufficient neutrons the arerage power must remain high. I'he results from the

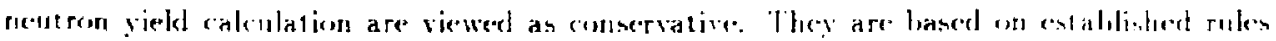


Table 8 : Key performance paramedere (thereretical).

Parameter

Average E-beam power

Target compeosition

Multiplication factur

Ceutron production

Tritium production per year

Vumber of units tos produce $5 \mathrm{~kg} \mathrm{~T} / \mathrm{yi} \quad \sim 12^{4}$

Power requirement per sustem

Direct capital cost per sistern

() $\&$. II consts per year
Baseline ('oncept $750.114^{\circ}$

Tungsten - Borgllium

1.5

$2.65 \times 10^{1 \mathrm{H}} \mathrm{n}:(\mathrm{arc})$

$0.41 \mathrm{~kg}$

$\sim 1070 \mathrm{MH}$

$\sim 85+011$

$\sim 81.5 .11$

Assumes a capacitr factur of $711 \%$

for neutron production derived from theoretical computations and experiment. The baselino neutron mutipliation factor is also considered conservative.

Foum an enginerering standpeint, the larget system is the major problem. Jo date. Jitule or now work has been completed on a target system concept. It is anticipated that the high average power of this acceletatur will create extremely difficult thermat management problems in the latget system. The a wo major problem arcas will be heat remowal in the target

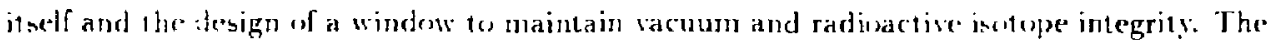
whlution to thene jor blems is nut anticipated to be near-term. Therefore. the conceptualized

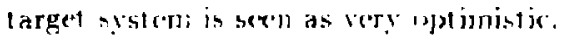

Finally. lake target cost data necds additional work. The figures assumed for the target system were extrapelated from a J976 report on the MT: project which used a deuterium accelerater t. convert fertile to fissile material. These costs were then converted w 1986 devilars, There is litte confideroce in the accuracy of these costs. 


\section{Developmental Status}

Since the inception of the FEL program (last $f$ to a years). approsimatcty sitt miltion toas been invested in acceleratur development and the F.IA II I Fixperimental Test Acreleratur I]) project. Accelerator technology. has reached a leved of maturity which permitted the FEL program. in conjunction with THW, to compete for the Ground Based Frec Electron Laser Technolog: Integration Experiment (GBFELTIE) at MSMH. It is estimated it will cost an additional $\$ 62$ nullion and take 29.4 man-years of effort tu develup this accelerater and provide a prototype at WSMR. The acrelerator in the tritium production device will be two to thice tinus more powerful than the WSMK device. Howerer. any progress made in the development of the $105.1 \mathrm{~K}$ accelerator would be applicable to the 1 ritium production machine. Hy comparison, the target systert is mot mature at all. We camnet hegin to anticipate the costs and required level of effort without much nore work.

\section{Developmental Issues}

\section{Drivers}

There are three major issues with the driver. The first issue inwolves attaining higher average power. Since neut ron production scales with average pumer. the best method af increasing

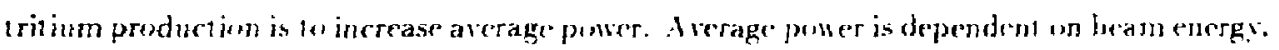
heam current. and pube widh and PRF. Raising beam energy alone will now accomplish

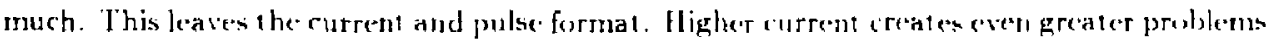
in bearn transpert. Lut the pulse format wfers a meathe of increasing average pulcer. The MSWh machite will have a PKF between 6 and $10 \mathrm{kHz}$. A higher rep rate /anch as uns machine ais ha (e) requires maltiplexing of two pulsed power trains. This. in turn. will raise custs dramatically. but it will incease average power. The second issue is that of acceleratur

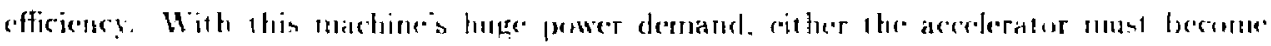

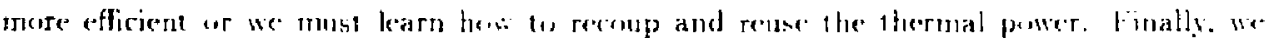


must make the transition from pulsed-puwer marbines to reliable cw machines. The thind issue, of accelerator reliability and cw operation, cncompasses the first two issues and will probably be the rasst difficult probiem.

\section{Targets}

The two most stressing issures with the target are thermal management within the target; pit area and development of a suitable window design. A third issue is that of enhanced neutron production and neutron multiplication with low- $Z$ materials. We ned to produce more neutrons from materials which tend to activate less. Finally. extraction of tritium from the target area is seen as a developmental issue. Hip desire safes and more efficient means of tritium e.traction. 


\title{
A DEUTERON LINAC FOR TRITIUM PRODUCTION
}

\author{
J.D. Lee
}

The potential for producing tritium with a deuteton linac (d-LISAC) is explored by adapting the results of a 1976 study that assessed the potential for producing fissile malerials 1. The 1976 study had as its origin the MTA project.

For this example an Alvarez linac produces $0.25 \mathrm{~A}$ of $500 \mathrm{Mcl}$ deuterens which are then used to produce tritium in a target assembly. Harameters for the 500 Mel linac arc listed in Table 9 . The target consists of a primary Li target surrounded by a Be and Li "condary target. In the 1976 study the secondary was l' and/or Th. The primary li target is $1.8 \mathrm{~m}$ in depth and produces two 105 Met average energ, neutrons per 50 Ml Mel deutcrom. 'The Be-li secondary. proposed here for tritium generation, supports multiplication of the high

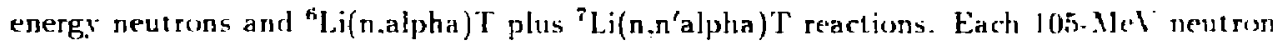
is taken to produce 6.28. tritons based on energetics scaled frum $1+$-Mel neutron calculations with Be-based blankets :2. Light-element targets are proposed because their lower prower density and generation of activation products would simplify target thermal design and waste management comp. red with the ase of heary eletnents. A watcr-cooled the primary and Be - LiAl secondary target should also be considered because it would climinate the nerd to handle liquid lithum and wuld utilize Savamah Hiver tafget lechonukgr:

An elevation view of how a d-LANAC tritinm production accelerator might look is shown in Fig. $T$ 


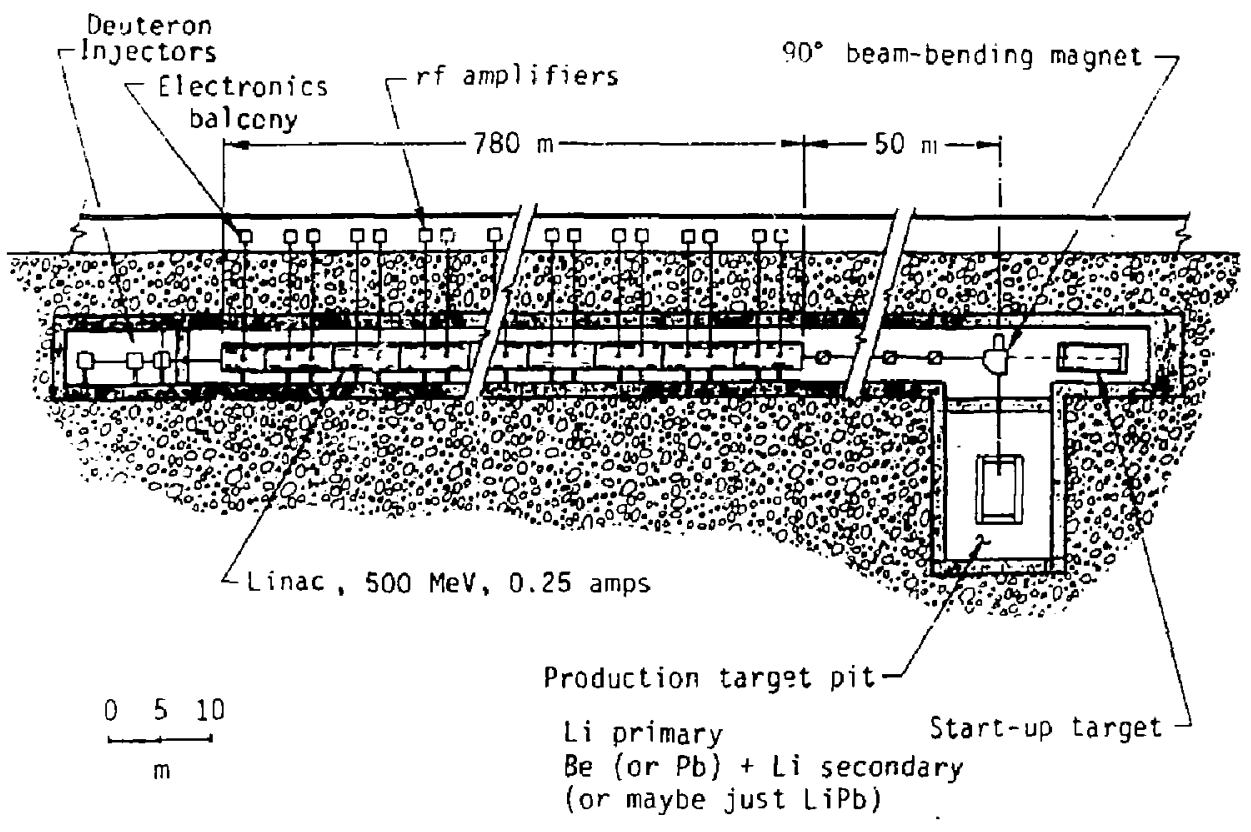

Figure 7 : d-LINAC'Case 
Table 9: Cicneral parameters for 500-MeY'. 0.25. A beam (cw) deuteren l.inac.

\begin{tabular}{|c|c|}
\hline Beam power $(\mathrm{MW}, \mathrm{cw})$ & 125 \\
\hline Injection energy $\left(\mathrm{keV}^{\prime}\right)$ & $750 \cdot 800$ \\
\hline Formalized emittance (inject: cm.mrad.) & $0.8 \cdot 1 \pi$ \\
\hline Minimum bore radius $(\mathrm{cm})$ & 2.25 \\
\hline Linac frequency $(\mathrm{MHz})$ & 50 \\
\hline A verage axial E-field $(\mathrm{MV} / \mathrm{m})$ & 1 \\
\hline Acceleration rate $\left(11 e^{i} / \mathrm{m}\right)$ & 0.620 .7 .9 \\
\hline Stable phase & $30^{\circ}$ \\
\hline Drift-tube quadrupole sequence & $N-1(\cdots)$ \\
\hline Integrated quadrupole strength (kG) & 15.7 \\
\hline Total of power $(\mathrm{MW})$ & 172 \\
\hline Number of cavities & 101 \\
\hline Linar length $(m)$ & $i 80$ \\
\hline Total power input $(111 \mathrm{y}$ at $60 \mathrm{~Hz})$ & 290 \\
\hline Injector & 1 \\
\hline Quadrupoles & 2 \\
\hline if syistem & 265 \\
\hline Auxiliary power (cooling. vacuum, rontrol) & 22 \\
\hline
\end{tabular}

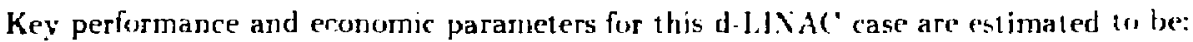

Areclerator deuteson energy and current $500 \mathrm{MeV} .0 .25$.

Tritium production sate $3.1 \mathrm{~kg}, \mathrm{YJ}$

Accelerator electrical power input $290 \mathrm{N1W}$

Capital cost, direct $\$ 422 \mathrm{M}$

() \& 11 costs per year (excluding \$18 M electricity and triium processing)

\section{R\&D Status and Issues}

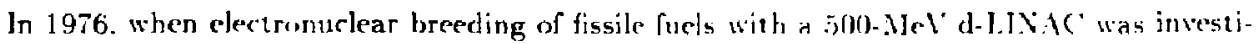
gated, the following accelerator Kd-ly issues mere listed:

- CW beam-current injection development is nerded.

- Alternative accelerator structures should be assessed to determite if there may be mure cost-effective optiuns.

- RF tube deredopment conld increase efficiency from $50 \%$ La $6570 \%$ 
In the targed performance area the following kdol) is needed:

- Theoretical and experimental verification of bears-target incractiun.

- Performance (T/d) rs vaste generation in light rs heavy secondary targets.

The time and cost associated with addressing ilie lkd I) needed to demonsi rate the reliable operation of a d-LINAC based tritium production facility has not been determined.

\section{References}

] C.M. Ian Atta, et al.. "The Electronuclear Conversion of Fertile to Fissile Matrerial." Lawrence Livermore National Laboratory, Livermore, CA, UCKL-52144 (1976).

2. R.11. Mloir et al., "Study of a Magnetic Fusion Production Reactor," Lawrence Livermore Jational Laboratory, Livernore, ('A. l'ChI-94408 (1986). 


\section{BLANKET AND TARGET R\&D STAT'US AND ISSUES}

Maximizing tritium production. thermal managemen1, material lifetime and replacentent. activation product generation, tritium handling-all must be satisfactorily arluiessed in the design of any blanket or target.

The tritium breeding blankets proposed for the Lincar Plasma and Tokamak Plasma fusion cases are based on mostly demonst rated techrolog: namely the Savannah Hiver watercooled LiAl target and tritium extraction technologies. Jesigns (concept ual) for both the linear and tokamak cases were addressed in some detail in Ref. 1. and 2. There are some uncertainties in the achievable 1 ritium breeding ratios $(=15 \%)$ and material lifetimes. but these uncertainties can be accommodated for by a modest increase in size and cust. In short, a major R\&I) program is not required; only a modest ( $<\$ 50.11$ ) design and testing offort is needed.

The breeding blanke! for the Compact Torus (C'T/HACE) fusion concept will require an $A \& D$ program. This is because the concept is new and radically different frome thase examined in the past. Development will be especially chalienging because the blanket must provide confinement for the plasma magnetic field as welt as breed tritiun. The larget tritium handling system will likely tave tu deal with the unburned L-T fucl alung with that produced in the blanket. Sixh an Rikl' program should be relatively shout-term and of modest cost ( $\$ 50.11)$ because of the small size of the ('T/ KACE concept. but its culcome is more speculative.

Trition hreeding largets for the accelerator-driven concepts will require some hd l) as outlined in the sections on these cases. It may also be posuible to use Savanah kiver-based

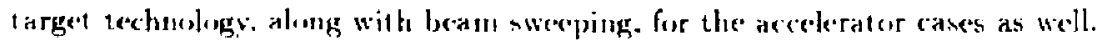




\section{References}

1) R.WV. Moir et al., "Study of a Magnetic Fusion Production Rosctur." Lawrence Livermore National Laboratory, Livermore, CA. UCRL-94408 (1986).

2. J.D. Lee, "Tritium Breeding Analysis of a Tokanak Magnetic Fusion Production Reactor." Laurence Livermore National Laboratory, Livermore, ('A, ll('RL-100019 (1988). 


\section{SUMMARY AND CONCLUSIONS}

To help give some perspective to the five potential tritium-producing concepts described above. Fig. 8 compares their est imated performance in terms of unit capacity clect rical power requirement, and cost. It also lists normalized performance in terms of the number of units required to produce $5 \mathrm{~kg} / \mathrm{s}$, the tritium produced per unit of electric energy $\left(\mathrm{kg} / \mathrm{G} \mathrm{H}^{\circ}\right)$. and the direct capital cost per unit capacity (SB/kg/y). The five concepts examined var: significantly in these figures of merit. As is normally the case. economy of scale prevails. and the tokamak with its large capaci $y$ of $13 \mathrm{~kg} / \mathrm{y}$ has the lowest cost in terms of construcion and electricity per unit of tritium production capacity. The CT/RACE concept is by far the smallest of the five in size as well as capacity; and a production facility based on (:T/R.AC:F would come closest to our desired jdeal of a small, modular sy'stem. The ('T/RA PE concept is also the most speculative of the five but an K\&D program through full-scale dernonstration should, by virtue of its small size, be much less costly in time and money than the others.

Bith respect to the two accelerator cases considered. the d-LINAC has the potential for relatively good performance, and its uncertainties and required $K \& D$ program appear to is, modest. The performance potential of the electron linac case was frund to be very low.

It should be pointed out that fission-based systerns have a prover record of reliable operation that make them the logical chorice in the near term and that will be hard to match even with mature fusion or acceleratur technologies. However, in view of the concern that even new fission production reactors conld be subject to unforeseen shuidowns in the fut ure. development of non-fission production methods (as backups or in addition to SI'R's) would enhance the overall security of tritium supply. Fusion-based tritium production deres hase

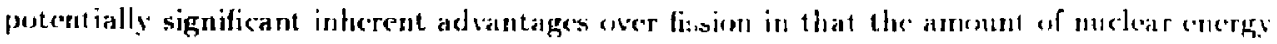




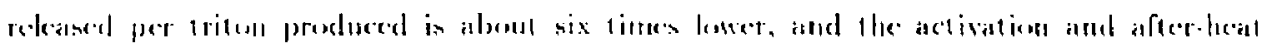
levels can be much lewer. These advantages arise from the fact that a DT fusion reaction produces a $1+\mathrm{MeY}$ neutron and a $3.6 \mathrm{MeY}$ alpha, compared to a fission reaction event which produces $200 \mathrm{Mel}$ and activated fssion products. Both events produre about 0.7 net tritions. These advantages were highlighted by the recent NRC' study and could result in real and/or perceived safety advantages. Accelerator-based systerns should have similar adrantages. 


\begin{tabular}{|c|c|c|c|c|c|c|}
\hline \multirow[t]{2}{*}{ Concept } & \multicolumn{3}{|c|}{ Unit Performance } & \multicolumn{3}{|c|}{ Normalized Performance } \\
\hline & $\underset{(\mathbf{k g} / \mathrm{y}=)}{\text { Capacity }}$ & $\begin{array}{l}\text { P(el) Req. } \\
\text { (GWel) }\end{array}$ & $\begin{array}{l}\text { Direct } \\
\text { Cost } \\
\text { (BS) } \\
\end{array}$ & $\begin{array}{l}\text { Units } \\
\text { for } 5 \mathrm{kgT} \\
\text { per year" }\end{array}$ & $\begin{array}{c}\text { T/E(el) } \\
\text { (kg/GWY) }\end{array}$ & $\begin{array}{c}\text { Direct Cost } \\
\text { (BS/kgT/yr) }\end{array}$ \\
\hline E-LINAC & 0.41 & 1.1 & $0.54^{* *}$ & 18 & 0.40 & $4.3^{* 4}$ \\
\hline d-LINAC & 3.1 & 0.29 & 0.42 & 2.3 & 11 & 0.19 \\
\hline Linear Plasina & 5 & 1.4 & 1.6 & 1.4 & 3.6 & 0.46 \\
\hline $\begin{array}{l}\text { Tokamak Plasma } \\
\text { (PPPL/LLNL) }\end{array}$ & 13 & 0.56 & 1.7 & 0.55 & 23 & 0.19 \\
\hline $\mathrm{RACE}, \mathrm{CT}$ & 0.027 & 0.0067 & $20.013^{* *}$ & 265 & 4 & $20.69 \cdot$ \\
\hline
\end{tabular}

- 70\% capacily factor

** Driver only, blanket-target systems not included

J. D. Lee

Figur: 8: C'omparison of peotential tritium prosduction technologies. 